\title{
BUDGETARY PROCEDURE IN ITS RELATION TO REPRESENTATIVE GOVERNMENT
}

\author{
W. W. WILLOUGHBY \\ Professor of Political Science, Johns Hopkins University
}

There are few terms in political nomenclature which have been used with such indefiniteness of meaning as has the word "budget." Frequently it is employed to designate the general appropriation act by which provision is made for the expenditure needs of a government for the next fiscal period. At other times it is used to indicate the revenue program presented by the executive for meeting the demands that are to be made upon the public treasury. In a third sense, it is applied to the material presented by the executive to the legislature for its information and guidance in determining its general financial program for the next fiscal year. It is in this third sense that the term will be employed in this paper.

Under all systems of public financial administration the legislature or fund-granting organ of government is supplied by the executive with a certain amount of financial information. In order, however, that the documents in which this is furnished may be said, collectively, to constitute a budget, it is necessary that the information which they contain should cover certain points, and that taken together they should be made to serve as a basis for a general financial program for the next ensuing fiscal period. When, then, a budgetary procedure is said to be employed by a state, it is meant that the following features appear in its system of financial administration:

First, that the legislature is furnished by the executive with the information needed by it for the intelligent performance of its function as the policy-determining organ of the government.

Second, that the legislature is aided by having presented to it a financial program framed by the executive, for the wisdom of which he assumes personal and political responsibility.

Third, that the legislature accepts the executive program thus presented to it as a working basis for its own action.

If this third feature were absent it might be possible for a state to have a budget without having its finances administered according to a system of budgetary procedure. ${ }^{1}$

\footnotetext{
${ }^{1}$ This was the situation in the United States in I9I3 when President Taft submitted to Congress what could properly be termed a budget, but to which that self-sufficient and independently minded body paid no attention.
} 
The United States operates without a budget, and, indeed, without any approach to a budgetary procedure. Congress does not obtain from the executive the information which it is entitled to have and which is indispensable if intelligent and wise financial legislation is to be enacted. The estimates which are submitted are but a mechanical compilation of the requests from the several spending services, each of which is bent upon obtaining for itself all that is possible from the public purse. That is, before submission to Congress, their requests have been subjected to no central supervision in order to see that their items are reasonable in amount, or that when aggregated they bear a proper relation to one another, and in their grand total are proportioned to the estimated or possible financial resources of the government as determined by a program of revenue legislation. The Secretary of the Treasury thus plays the part merely of an agent of transmission, and the President plays no part whatsoever, the only functions which Congress has seen fit to impose upon him in the premises being that in case it appears that there will be a deficit, he shall "advise the Congress how in his judgment the estimated appropriations could with least injury to the public service be reduced so as to bring the appropriations within the estimated revenues." This provision dates only from I909, and it may be said that the presidents have not seen fit to pay any attention to the obligation thus imposed upon them. The reason for this undoubtedly is that they have seen the futility of making such recommendations, well knowing that Congress would attach no value to them, and that in fact, despite their legislative declaration, they would not welcome them. For the same reason, no President has made use of his constitutional right and duty to "give to the Congress Information of the State of the Union, and recommend to their Consideration such Measures as he shall judge necessary and expedient," in order to present a formulated and comprehensive financial program for congressional consideration.

Not only has Congress failed to provide for the keeping and submission to itself by the executive of the fiscal information which is indispensable to intelligent legislation, and shown in an unequivocal manner that it will not receive with cordiality a fiscal program prepared by the executive, but it has not organized itself in such a manner as to centralize responsibility in a budget committee of its own creation with jurisdiction over revenue measures as well as over acts carrying appropriations. It has not even placed appropriations within the control of a single committee, but has distributed this power among eight or more separate committees.

The failure of the United States to develop a budget or to employ budgetary methods is a remarkable fact. Even if it were not true that, alone among all the modern constitutional states of the world, the United States attempts to administer its finances without co-operation between the executive and legislative branches of the government, the advantages of a budget prepared by the executive are so obvious that I 
shall not take time to enumerate them. That eminent investigator, Sherlock Holmes, is reported to have said, on one occasion, to his friend Dr. Watson, by way of rebuking his incredulity: "Exclude the impossible and whatever remains is possible, however improbable." This sapient remark has its application here. It would seem almost incredible that Congress should have refused to avail itself of the executive assistance it might have in matters of financial policy, but that it is possible, however improbable, the facts declare. What is the explanation of this condition of affairs?

Until recently we in this country have been so fortunately circumstanced that it has not been imperatively necessary for us to administer our finances with economy and efficiency. It has been so easy to obtain public funds without oppressively burdening the people that we have not been compelled to determine with scrupulous care just what expenditures shall be authorized, or to guard vigilantly the spending services in the use by them of the amounts placed at their disposal. But this condition of affairs no longer exists. Even before the entrance of the United States into the present Great War, the need for better methods of financial administration had become evident not only in the national government but in the states and cities and other administrative areas. And now that the expenditure of vast amounts is demanded for the prosecution of the war and the giving of aid to our allies, this need has become an imperative one. Though we may trust that the war itself will not long continue, not only will it leave an inheritance of a greatly increased public debt which will impose for many years a large fixed charge upon our public revenues, but there will doubtless result a permanent widening of the sphere of governmental action both in supervision and control of private industries, and in actual administration and operation. Increased demands upon the public purse will be inevitable.

There is no danger that the greater importance of proper systems of financial administration will not be recognized by those who exercise political influence in this country, nor do I think that the technical merits of budgetary methods will be denied. It is, however, none the less certain that the movement for the introduction in this country of true budgetary methods will not be an unresisted one. The opposition to it already shown in many influential quarters sufficiently evidences this. This opposition, shortly stated, is founded upon the proposition that the budget system is not compatible with the general character of our system of constitutional government, or more specifically, that its use would tend to disturb that relation or balance between the executive and legislative branches of the government which American political philosophy has held to be indispensable to a proper protection of the liberties and interests of the people. And thus I am led to the real point which I wish to discuss in this paper-which, indeed, goes to the very heart of the whole problem not only of public financial 
administration but of popular government itself ; namely, what are the respective parts that, in any system of representative rule, it is desirable or feasible that the executive and legislative branches of government should play, and what light is thus thrown upon the question as to the best manner in which the financial program of the state may best be framed and executed? Or, reversing the terms, the question is: what light do the practical necessities of efficient financial administration throw upon the general question as to the functions which it is feasible or desirable, in a representative democracy, for the legislative and executive branches respectively to perform?

As regards generally the proper functions in a popular government of the elected representative body, it is perhaps unfortunate that it should be known simply as "the legislature," for the result has been unduly to emphasize its lawmaking function and to obscure the other important functions which it should perform. Indeed, there is good ground for holding that it is not necessary, in order that true popular government be realized, that the representative body should be primarily legislative at all, at least in the sense of formulating and initiating the policies to be adopted by the state; but that the essential purposes for which it exists are secured when it operates as the organ for giving the final sanction to the policies which are submitted to it by the executive, and for holding all administrative officials to a strict political accountability for the manner in which they have exercised the powers entrusted to them, and when, in addition, it has served as the central organ through which the public will is made known and its censure, when necessary, applied to those in public authority.

John Stuart Mill in his essay on Representative Government, published in I86r, has a remarkable chapter entitled of the Proper Functions of Representative Bodies. After pointing out that there is a radical distinction between controlling the business of government and actually doing it, and that the latter is a task which no numerous assembly should attempt to perform, Mill goes on to say that

"it is equally true . . . that a numerous assembly is as little fitted for the direct business of legislation as for that of administration."

"The proper duty of a representative assembly in regard to matters of administration," he continues, "is not to decide them by its own vote, but to take care that the persons who have to decide them shall be the proper persons."

\section{And again he says:}

"Instead of the function of governing, for which it is radically unfit, the proper office of a representative assembly is to wateh and control the government: to throw the light of publicity on its acts; to compel a full exposition and justification of all of them which any one considers questionable; to censure them if found condemnable, and, if the men who compose the government abuse their trust, or fulfill it in a manner which conflicts with the deliberate sense of the nation, to 
expel them from office, and either expressly or virtually appoint their successors. ... This," he declares, "is surely ample power, and security enough for the liberty of the nation."

Mill goes on to point out, however, that

"the Parliament has an office, not inferior even to this in importance; to be at once the nation's Committee of Grievances, and its Congress of Opinions: an arena in which not only the general opinion of the nation, but that of every section of it, and as far as possible of every eminent individual whom it contains, can produce itself in full light and challenge discussion."

And Mill concludes this remarkable chapter by saying:

"Nothing but the restriction of the function of representative bodies within these rational limits, will enable the benefits of popular control to be enjoyed in conjunction with the no less important requisites (growing ever more important as human affairs increase in scale and in complexity) of skilled legislation and administration."

It is a striking tribute to Mill's political genius that the development of representative government in Great Britain has followed the lines indicated by him, until by the end of the nineteenth century the British Parliament had come to function almost precisely as he had indicated it should do.

Thus in England we have a government which without weakening the executive energy, or indeed abolishing the form of monarchy, has carried to its highest and most successful degree the art and practice of representative government. Efficiency in executive action and efficiency in administration have there been secured without a sacrifice of the essential requirements of popular government. By successive steps, though not always without revolutionary action, the autocratic and personal powers of the king were diminished, and executive authority brought under the control of the representatives of the people in Parliament assembled. But guided by what would appear to be political intuition rather than by reasoned connection, the English Commons has never attempted (unless we except certain years under the Commonwealth) either to lessen the executive powers of the government or itself to exercise them. The distinction between executive and legislative power was not lost sight of, and the House of Commons has sought to bring the exercise of executive authority under its control and supervision, but not to weaken it. It is one of the most striking facts of English constitutional history that along with the development of popular government and a constantly increasing authority and prestige of the elected branch of the Parliament has gone an increase rather than a decrease in the legal powers of the executive-powers which even in times of peace have been constantly added to, so that it is correct to say that by legal definition and establishment the powers 
of the English crown are to-day more extensive than they were in the times of the Tudors or Stuarts. Indeed, there are few constitutional monarchs in the world whose legal powers are equally extensive. Correlative to this has been the policy of the Parliament, consistently pursued, to refuse itself to exercise functions essentially executive in character. Thus it may be doubted whether there can be found in the world a popularly elected legislative body which keeps itself so free as does the British House of Commons from the exercise of executive functions. It is equally true that nowhere else can a government be found in which those who possess and exercise executive or administrative powers are held to such strict legal and political responsibility for the manner in which and the discretion with which they execute the functions of their several offices. Functionally, executive and legislative powers are kept distinct in the British Government; in operation, they work in harmony and co-ordination.

Under the British system the nominally legislative body has not only refrained from itself attempting the exercise of functions logically belonging to the executive, but it has also been content to entrust the chiefs of that branch of the government with the task of formulating the general public policies which are to be the subject of legislative discussion-and chief among these public policies are, of course, those connected with the raising of revenues and the placing of supplies at the disposal of the crown.

Just what weight should be given in the legislature to the proposals of the executive contained in the estimates is, of course, a matter of great importance. Indeed upon this, more than upon any other one point, the actual character of the constitutional government which a state is to have may be said to depend.

In England, the financial proposals of the executive are practically controlling upon the legislature. By a self-denying ordinance which has been continuously in force for more than two hundred years, the House of Commons has declared that it

"will, receive no petition for any sum relating to public service, or proceed upon any motion for a grant or charge upon the public revenue, whether payable out of the consolidated fund or out of money to be provided by Parliament, unless recommended by the Crown."

This still leaves it within the power of the Commons to reject or reduce items of expenditure recommended by the executive, but in fact, so strictly does the party system operate that the entire financial program of the ministry is always adopted without substantial change, and indeed without discussion of many of its proposals. And as regards revenue measures, so certain is it that executive proposals will receive legislative approval, that their provisions are put into force immediately after they are made public in the so-called "budget speech" of the Chancellor of the Exchequer. The legality of this practice hav- 
ing been denied a few years ago in the courts, a permanent act of Parliament was passed specifically legalizing the practice.

In Canada there is the constitutional provision in its fundamental act of government-the British North America Act of 1867 -that

"it shall not be lawful for the House of Commons to adopt or pass any vote, resolution, address or bill for the appropriation of any part of the public revenue or of any tax or impost, to any purpose that has not been first recommended to that House by message of the Governor General in the session in which such vote, resolution, address, or bill is proposed." (Sec. 54.)

In Canada, as in England, the party system operates to secure the almost certain and unchanged adoption by the Parliament of the budget proposals of the ministry.

In the constitution of the Commonwealth of Australia there is a provision similar to the one quoted from the British North America Act.

In constitutional monarchies like Prussia and Japan the budgetary proposals have an almost overwhelming weight in the legislatures, but this is due not to the working of party government, but to the constitutionally dominating powers of the executive.

In France and Italy the budgetary system exists, but though accepted as a working basis, the financial proposals of the executive are freely amended-and, it may be observed, with most unfortunate results. Indeed, the testimony of experience the world over is that a popularly elected legislative chamber cannot be trusted to practice due economy in the matter of authorizing expenditures from the public purse. The wisdom, therefore, of the standing order of the British House of Commons which has been quoted, and of the provisions of the Australian Commonwealth and of the British North America Act cannot be impeached.

The writer is not prepared to say that the United States should adopt en grosse the parliamentary system of Great Britain. Nor is he ready to propose that Congress should be given the power to expel the executive from office-although it may be said parenthetically that this power is in fact possessed in Great Britain by the electorate rather than by the Commons, for it has been many years since a British ministry has been obliged to resign because of a failure to obtain parliamentary support for its policies. What does appear plainly is that the English system is far superior to ours so far as its representative body submits to executive direction, and so far as it compels that executive to supply it with the information which is needed in order that it may not only pass an intelligent opinion upon the measures presented to it, but give publicity to their acts and pass judgment upon the economy, efficiency and honesty with which the affairs of the government have been administered. 
These propositions have a direct and important bearing upon matters of financial policy, for as must plainly appear, it is especially within this field that the fund-raising and fund-appropriating and policy-determining body is in need of information and advice which only the executive is competent to give. It is unfortunate that the proper use of executive information and advice has been prevented in this country through a mistaken interpretation of what is known as the principle of "separation of powers,"-force being given to it in political practice which is not inherent in it as a constitutional doctrine.

As a constitutional doctrine, the theory holds that a people can be made secure in their private and public rights only if the exercise of executive, judicial and legislative powers are vested in different organs of government, each as free as possible from legal control by the others. As a matter of political practice, however, it is indispensable that these three great branches of the government should operate in harmony and co-operation; and it is especially important as regards the executive and the legislature that there should be no jealousy by one of the power and influence of the other, so long as constitutional limits are not overstepped or endangered.

By a process of historical development the operation of the British Government has been brought, as we have seen, to that happy condition in which the executive and legislative powers, though never confused, are exercised in almost complete harmony and resulting efficiency. In the United States this result has not been secured and there still persists on the part of Congress a jealousy of the power and influence of the President which has prevented Congress from encouraging or even permitting the development of executive practices which, if employed, would not only greatly increase administrative efficiency, but would put Congress itself in a more satisfactory position to exercise its functions as an organ of legislation and as a board of supervision and control of the administrative services.

If we consider the subject wholly from the standpoint of conserving to Congress its full influence and power as the policy-forming and supervising organ of government, it is clear that in matters of finance Congress is of right entitled to demand that the executive shall give it the following information:

I. An accurate and intelligent statement of the condition of the public treasury.

2. An estimate of the revenues to be received by the state from existing sources of income.

3. A statement of the expenditures of the last-completed or immediately preceding fiscal year, and an estimate of the expenditures that will probably be made during the current year.

4. A statement of expenditure needs for the government during the next fiscal period. 
The character and content of these exhibits deserve more specific description. The statement as to the condition of the Treasury now submitted to Congress shows little more than the actual cash on hand. To be adequate, it should be upon an accrual basis, and should clearly exhibit the status of all trust and other special funds, including the funds which each appropriation creates. It is also highly desirable that the showing thus made as of the date of the ending of the last fiscal year should be accompanied by comparative tables showing the corresponding totals for one or more of the years immediately preceding. The probable condition of the Treasury at the close of the current year should also be exhibited, as well as the Treasury situation to be expected at the close of the coming fiscal year in the light of the estimates and expenditures and receipts for that year. There are some accountants who hold that this Treasury balance sheet should also show the property assets in the way of buildings, supplies on hand, etc., but it is the opinion of the writer, for reasons that have already been given, that no useful purpose would thereby be served. However, as will later be pointed out in connection with the statements of expenditures, capital outlay and fixed charges should be distinguished from current expenses and the value and amount of materials on hand at the opening and close of the fiscal year should be indicated.

In the statement of revenues should appear in parallel columns the revenues for a series of years including those estimated for the current and the coming year. So far as possible, all distinct sources of revenue should be indicated in one table, and in another table the same revenues should be given according to organization units. Care should be taken to include "reimbursable" items and proceeds from the sale of material, and all miscellaneous receipts from fees, rents, charges for services rendered, etc.

The adequate presentation to Congress of expenditures is a more difficult matter than is the preparation and submission of revenue statements. These statements of expenditures are required in order that Congress may accurately estimate the needs for the coming year, and that it may determine the economy and efficiency with which past operations of the government have been conducted. By determining this matter of administrative economy and efficiency, Congress is enabled to fix administrative responsibility, and incidentally to limit appropriations for the future to sums which, while sufficient, will prevent wasteful and extravagant expenditures.

For the purpose both of oversight of the administration and of making financial provision for the next fiscal year, it is, therefore, indispensable that expenditures should be reported in five different forms, namely, according to (I) funds, upon which chargeable; (2) character-i. e., capital outlay, fixed charges, and current expenses; (3) organization units; (4) activities-i.e., pieces of work done or distinct 
services rendered; and (5) objects-i. e., materials or personal services purchased.

Only when expenditures are thus reported is it possible for the fundgranting and directing authority to determine what returns have been obtained from the expenditures previously authorized, what each department, bureau or other governmental establishment has actually cost for maintenance and operation, and what expense each particular piece of work done for the government has entailed.

It need not be pointed out that returns such as those indicated above cannot possibly be made unless the several spending services maintain uniform and appropriate accounts, including cost-accounts. At the present time, except in a few instances, no such classified expenditure accounts are kept, nor is there any approach to uniformity of presentation where they are kept. In general, such accounts as are kept indicate little more than the disbursements made by the various disbursing officers, and the Treasurer of the United States does not even make a report of disbursements according to appropriation accounts, although this information is of course recorded upon his books. Furthermore, there are no reports made by the various auditors, nor any comprehensive statements of audited items such as are made by the Auditor General in Canada and the Comptroller and Auditor General in Great Britain. If, then, Congress is to obtain the information concerning expenditures which it is entitled to have, it is necessary that a statute provide that proper basic accounts be kept in all the services of the government and that the annual reports should be based upon them.

The fourth set of facts, as previously enumerated, to which Congress is entitled is a statement from the administrative services of their financial needs for the coming year. As to classification, there can be no doubt that it should be according to organization units and that each appropriation head should be adequately itemized.

In the immediately preceding paragraphs a description has been given of the kinds or classes of informational data which should be supplied to Congress. We turn now to the question whether the book of estimates in which this information is contained should be a mere mechanical compilation of the data supplied by the several government services, or whether before being sent to Congress these requests should be submitted to a central official who shall be authorized to revise them, and to transmit them to Congress as his own estimatesthat is, as estimates for whose correctness and wisdom he is personally and politically responsible.

In any system of financial administration, the need for a revision and co-ordination of the original estimates of various bureaus and departments is due to two facts-one of knowledge, and the other psychological, as characteristic of human nature itself. As regards the matter of knowledge, it is clear that the heads of the several sub- 
divisions of the administrative service cannot be expected to have exact information concerning the needs of services other than their own, or of the government as a whole. As regards the psychological or subjective element, it is but natural and, indeed, laudable that each head of the bureau should emphasize the value of the services which he directs, should seek to increase its scope and importance, and therefore be disposed to ask for corresponding financial support. Thus, it is to be expected that he will ask for all that he can possibly hope to get without regard to the demands of the other services.

In the United States, only the President could effectively exercise this revisionary power. The only other official to be thought of in this connection would be the Secretary of the Treasury, but if the authority were vested in him it would inevitably become merely a matter of form, the real discretion being exercised by the President. This would necessarily result from the official relation in which the Secretary of the Treasury, as well as the heads of the other great executive departments, stand toward the President, and from the fact - which has earlier been pointed out-that it is always possible for the President, through his constitutional powers of appointment to and dismissal from office, to secure members of his Cabinet who are in accord with his policies.

It is clear that there would be no constitutional objection to the development or express statutory authorization of such a system in this country. Indeed it is doubtful whether statutory authorization to the President to revise the estimates would be needed. Even the repeal of existing statutes would not be essential, as the episode of the Taft administration showed, except to prevent the expense of preparing the estimates according to the old forms for submission by the Secretary of the Treasury directly to Congress. As a practical matter, however, it would be necessary for Congress to provide a corps of officials organized as a budget bureau or bureau of administrative control for collecting and compiling the material which the President would need in order to prepare for Congress the various informational documents which have been described.

That the introduction of budgetary methods would result in a considerable increase in the political influence and prestige of the President cannot be doubted; and that the estimates as thus revised and submitted would have a weight which would make it less easy than it now is for Congress to depart from them, is also reasonably certain. The question before the American people reduces itself to this: Is there really any objection to giving the President a greater influence than he now exerts in matters of financial legislation? Or, if there is an objection, is it of a character sufficiently serious to warrant our foregoing the advantages which might be obtained?

All persons who understand the principles of public financial administration and who are also able to view the matter without 
personal or political bias, will have no hesitation in answering that the advantages certain to accrue from subjecting the departmental estimates to presidential revision should be secured. And there are few students of the science of government and of the American constitutional system who see any disadvantages that would result from an increase in the President's power and influence in matters of financial administration.

In fact, the upholders of the existing systems are obliged to draw back their arguments into their last trenches of defense and to assert that it is inconsistent with the idea of representative government to which American political philosophy stands committed, that the representatives of the people in Congress assembled should divide with the executive the responsibility for the public policies, financial or other, which are to be adopted.

The hollow character of such an argument is, however, apparent. In the first place the President is elected by and is as much a representative of the people as are the members of the legislature. In one sense, indeed, he is a truer representative than they, for he alone is the choice of and represents the interests of the whole people, while the members of Congress each represents but a relatively small constituency. But even if this were so, and if, arguendo, it were to be conceded that the will of the people should find utterance exclusively in the resolutions and enactments of Congress, it still would not follow that it would be inconsistent with the fundamental principles of republican or representative government to permit the executive to make recommendations which can have no legal force until adopted by the legislative body.

Stripped then of all sophistries, and leaving aside the matter of unreasoning conservatism, the only explanation why Congress has been unwilling that the estimates should be submitted and revised by the President (or by an official responsible to him), is that it has not wished to increase his political influence. The certainty of economy and efficiency in the administration of the affairs of the nation has been insufficient to overcome that unwillingness. 